\title{
Life history characteristics of the clam Mya arenaria in the White Sea
}

Received: 30 January 2002 / Revised: 10 February 2003 / Accepted: 11 February 2003 / Published online: 27 March 2003 (C) Springer-Verlag and AWI 2003

\begin{abstract}
Dynamics of Mya arenaria beds in two bights of the Chupa Inlet (Kandalaksha Bay, White Sea) were studied on a long-term basis. Observations were carried out at 1 - to 3-year intervals from 1979 up to 1999. The studied soft-shell clam beds were characterised by a substantial instability of age structure. Since 1988, only one year-class has dominated in the beds while other generations have been scarce and recruitment was not observed. This pattern of Mya bed dynamics was related neither to interannual environmental changes nor to differential reproduction success or predation effects in the benthic assemblages. Favourable conditions for spat formation in 1988 (low abundance of other M. arenaria generations), as well as for juvenile survival during the following winter, resulted in high abundance of juveniles in both investigated locations in 1989 . The mortality rate $(\mu)$ in this 1988 generation varied throughout the period of investigation and was related to age. The mortality level decreased for the first 2-4 years of the life cycle, then stabilised for the next 3-4 years, and eventually increased in subsequent years. Overall $\mu$ values ranged from 0 to 1.68 year $^{-1}$. The oldest specimens observed were 17 years old and had a maximum shell length of $79 \mathrm{~mm}$. Significant differences in average growth rates were observed between molluscs of different locations.
\end{abstract}

Keywords Mya arenaria $\cdot$ Life history · Population dynamics - Growth rate . The White Sea

Communicated by H.-D. Franke

N. V. Maximovich (®) A A. V. Guerassimova Department of Ichthyology and Hydrobiology, St. Petersburg State University, 16th Line VO 29, 199178 St. Petersburg, Russia e-mail: Hydro@np4140.spb.edu

Tel.: + 812-3213279

Fax: $+812-3280852$

\section{Introduction}

The soft-shell clam Mya arenaria L. is a common component of soft-bottom littoral benthic assemblages in the temperate zone of the Northern Hemisphere. In the Atlantic Ocean, this species reaches as far south as the Bay of Biscay and Northern Carolina. In the Pacific, it occurs as far as California and the Japanese Sea (Golikov et al. 1985). In the White Sea, M. arenaria usually forms tight beds of more than 1,000 ind. $\mathrm{m}^{-2}$ (Russanova 1963), which can easily be sampled. Hence the species is a convenient object for investigations on population dynamics.

M. arenaria population dynamics has previously been studied in a number of locations, including the White Sea (Glude 1954; Brousseau 1978; Maximovich 1978, 1989a; Commito 1982; Goshima 1982; Sadykhova 1982; Möller and Rosenberg 1983; Brousseau and Baglivo 1984; Emerson et al. 1988). These investigations have revealed large interannual variations in population recruitment rate. For this reason, Mya beds can consist of only adult specimens for several years. Different explanations of this phenomenon have been proposed. Some authors (Beukema 1982; Günter 1992) suggested fluctuations of recruitment rate resulting from interannual variation in reproduction success. Commito (1982) emphasised the role of predators in regulating the recruitment level, while Kühl (1951) pointed out that the ice regime could play a crucial role in this process. Some researchers considered the variation of recruitment level as a result of adult-larval interactions (Möller and Rosenberg 1983; Maximovich 1989a; Günter 1991, 1992). According to Günter (1992), the scarcity of juveniles in the North Sea populations could be the result of filtration activity of adult molluscs. It was also shown (Günter 1991) that repellents produced by adult specimens often control the rate of spat fall. Experimental studies have revealed weak spat formation in beds with high numbers of adult specimens (Andre and Rosenberg 1991). However, other observations did not confirm this correlation (Brousseau and Baglivo 1988; Günter 1992). Thus, there is no common opinion about 
the reasons of recruitment rate instability in $M$. arenaria populations and further studies are necessary.

Probably the main reason for the inconsistency of the obtained results is that observation periods were relatively short, rarely exceeding $2-3$ years. This is clearly insufficient for studies of population dynamics in a species whose lifespan can be as long as 28 years (MacDonald and Thomas 1980; Appeldoorn 1990). Our studies at the White Sea Biological Station of St Petersburg State University (WSBS) have been carried out for 20 years, and have provided extensive data on $M$. arenaria population dynamics in the White Sea.

The growth patterns of soft-shell clams are fairly well studied in some parts of their geographical range. Their lifespan varies from 4 to 28 years while maximum length ranged from 27 to $125 \mathrm{~mm}$ (Swan 1952; Münch-Petersen 1970; Feder and Paul 1974; Warvick and Price 1975; Evans and Tallmarc 1977; Brousseau 1979; MacDonald and Thomas 1980; Commito 1982; Winther and Gray 1985; Emerson et al. 1988; Appeldoorn 1990). Among the key factors determining $M$. arenaria growth rate in natural conditions are temperature, current velocity, exposure time, type of sediments, water salinity and food availability (Ivanov 1973; Sadykhova 1979; Swan 1952; Newell and Hidu 1982; Rosenberry et al. 1991). In the White Sea, however, little is known of the growth rate of the soft-shell clam. The species' maximum lifetime here is 13-14 years (Sadykhova 1979; Maximovich 1989a), but no data are available on the degree and causes of growth rate variation in local populations. The aim of the present study was to reveal the main traits in the dynamics of population structure and growth rate in some intertidal beds of M. arenaria in the White Sea.

\section{Methods}

M. arenaria beds were studied in two bights of the Keret archipelago (Chupa Intlet, Kandalaksha Bay, White Sea) in the vicinity of the WSBS (Fig. 1). Observations were carried out at 1-3 year intervals from 1980 (location A) and 1979 (location B) up to 1999 (both locations). Sampling took place mostly between late June and early July. In both locations, middle and low intertidal zones were sampled separately.

At each site (intertidal horizon) molluscs were sampled together with other macrobenthic invertebrates using a series of frames of 0.01-1 $\mathrm{m}^{2}$ catching square. For registration of Mya specimens of less than $20 \mathrm{~mm}$ in length, frames of $0.01-0.1 \mathrm{~m}^{2}$ catching square were used depending on clam abundance. Frame size was chosen in such a way that, on average, samples did not include less than 10 individuals each. At each site, at least 10 samples were taken in each sampling period. Sediments were excavated to $5 \mathrm{~cm}$ depth using a spoon and then washed out through a sieve of $1 \mathrm{~mm}$ mesh size. For registration of large molluscs (more than $20 \mathrm{~mm}$ ), frames of $0.25-1 \mathrm{~m}^{2}$ catching square were used. The choice of frames was based on the same consideration as in small molluscs. Again, a minimum of 10 samples was taken at each site and sampling time. Sediments were excavated to $30 \mathrm{~cm}$ depth using a spade. Overall, 1132 samples were collected during the investigation.

Clams from each sample were counted and their shell length was measured to the nearest $0.1 \mathrm{~mm}$. The numbers of molluscs of both size fractions (smaller and larger than $20 \mathrm{~mm}$ ) were then calculated per square metre and lumped together to give the total number per square metre at each sampling site.
Mollusc age was determined by counting shell annuli. Age determination on the basis of external shell morphology is known to be rather troublesome (MacDonald and Thomas 1980; Appeldoorn 1983). Nevertheless, according to many authors (Newcombe 1936; Swan 1952; Feder and Paul 1974) the structural marks on $M$. arenaria shells do reflect annual growth patterns. Some peculiarities of the studied Mya beds have allowed us to check the correctness of age determination on the basis of external shell morphology. Since 1989, a single year-class has prevailed in the mollusc beds in both locations. Hence, at every sampling session we knew the exact age of the molluscs of the dominating group and could thus assess the reliability of age determination on the basis of shell annuli analysis. It was found that the first annuli (corresponding to the growth delay during the first winter after settlement) was not visible in specimens older than 2 years. Taking this into consideration, and counting the number of visible 'growth rings' on the shells, it was possible to estimate the real mollusc age quite confidently.

Comparative analysis of abundance dynamics in $M$. arenaria generations was performed using the mortality coefficient $\mu\left[\right.$ year $\left.^{-1}\right]$ :

$\mu=\ln N_{1}-\ln N_{2}$

where $N_{1}$ and $N_{2}$ are abundances (ind. $\mathrm{m}^{-2}$ ) of a special age-class in successive years.

Growth rates of $M$. arenaria were studied by measuring the maximum linear size of shell annuli. These were measured in the majority of caught molluscs (about 5,000 specimens overall). Average characteristics were then calculated for each tidal horizon in each location. For growth pattern reconstruction the Bertalanffy equation was applied:

$L_{t}=L_{\infty}\left(1-\exp ^{-k\left(t-t_{o}\right)}\right)$

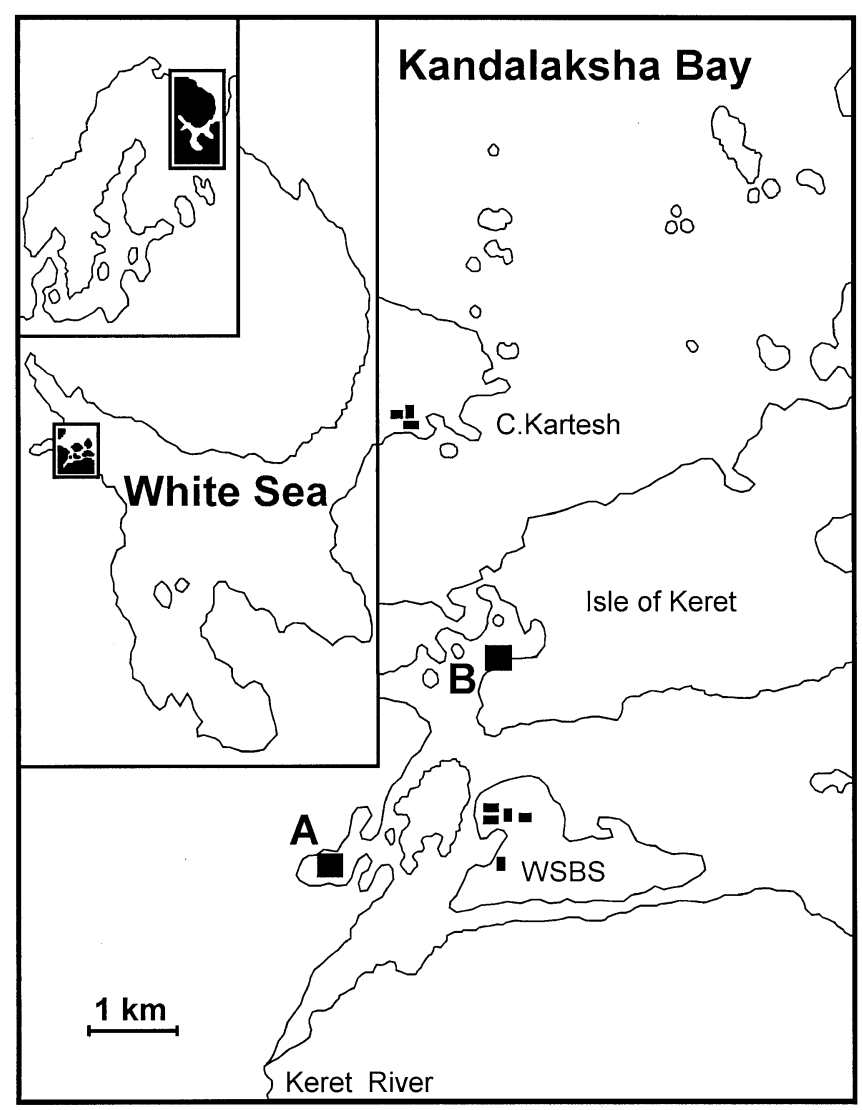

Fig. 1 Area of investigation. A and B, investigated locations 
Table 1 Abundance $\left(\mathrm{N}\right.$, ind. $\left.\mathrm{m}^{-2}\right)$ and biomass $\left(\mathrm{B}, \mathrm{g} \mathrm{m}^{-2}\right)$ of main macrozoobenthos components in middle and low intertidal zones at location A in 1983, 1990 and 1998. Note: +indicates biomass of less than $0.01 \mathrm{~g} \mathrm{~m}^{-2}$

\begin{tabular}{|c|c|c|c|c|c|c|c|c|c|c|c|c|}
\hline \multirow[t]{3}{*}{ Species } & \multicolumn{6}{|c|}{ Middle intertidal zone } & \multicolumn{6}{|c|}{ Low intertidal zone } \\
\hline & \multicolumn{2}{|l|}{1983} & \multicolumn{2}{|l|}{1990} & \multicolumn{2}{|l|}{1998} & \multicolumn{2}{|l|}{1983} & \multicolumn{2}{|l|}{1990} & \multicolumn{2}{|l|}{1998} \\
\hline & $\mathrm{N}$ & $\mathrm{B}$ & $\mathrm{N}$ & $\mathrm{B}$ & $\mathrm{N}$ & $\mathrm{B}$ & $\mathrm{N}$ & $\mathrm{B}$ & $\mathrm{N}$ & B & $\mathrm{N}$ & B \\
\hline Mya arenaria $\mathrm{L}$. & 84 & 380.30 & 845 & 284.51 & 32 & 237.72 & 87 & 406.02 & 1,142 & 376.66 & 79 & 346.10 \\
\hline Mytilus edulis L. & - & - & 2 & 30.48 & 1 & 3.92 & 32 & 194.00 & 6 & 1.43 & 8 & 9.00 \\
\hline Macoma balthica L. & 4 & 0.80 & 52 & 10.68 & 90 & 42.60 & 27 & 0.70 & 42 & 8.49 & 126 & 40.38 \\
\hline Hydrobia sp. & 1,046 & 10.00 & 5,080 & 1.60 & 940 & 8.50 & 912 & 7.70 & 3,165 & 31.65 & 720 & 5.95 \\
\hline Polychaeta var. & 263 & 11.08 & 162 & 0.73 & 36 & 1.84 & 115 & 8.00 & 530 & 13.11 & 124 & 2.64 \\
\hline Littorina littorea $\mathrm{L}$. & 12 & 1.96 & 2 & 0.03 & 2 & 0.46 & 6 & 1.00 & - & - & - & - \\
\hline Chironomidae var. & - & - & 6 & 0.02 & - & - & - & - & 10 & 0.03 & - & - \\
\hline Gammaridae var. & - & - & 8 & + & - & - & 10 & 0.30 & 20 & 0.03 & 120 & 0.18 \\
\hline $\begin{array}{l}\text { Littorina saxatilis } \\
\text { Olivi }\end{array}$ & - & - & - & - & 6 & 0.04 & 62 & 2.50 & - & - & - & - \\
\hline Oligochaeta var. & 220 & 1.00 & - & - & - & - & 140 & 0.50 & - & - & - & - \\
\hline Total & 1,629 & 405.14 & 6,157 & 328.05 & 1,107 & 295.08 & 1,391 & 620.72 & 4,915 & 431.40 & 1,177 & 404.25 \\
\hline
\end{tabular}

Table 2 Abundance $\left(\mathrm{N}\right.$, ind. $\left.\mathrm{m}^{-2}\right)$ and biomass $\left(\mathrm{B}, \mathrm{g} \mathrm{m}^{-2}\right)$ of main macrozoobenthos components in middle and low intertidal zones at location B in 1979, 1991 and 1999. Note: + indicates biomass of less than $0.01 \mathrm{~g} \mathrm{~m}^{-2}$

\begin{tabular}{|c|c|c|c|c|c|c|c|c|c|c|c|c|}
\hline \multirow[t]{3}{*}{ Species } & \multicolumn{6}{|c|}{ Middle intertidal zone } & \multicolumn{6}{|c|}{ Low intertidal zone } \\
\hline & \multicolumn{2}{|l|}{1979} & \multicolumn{2}{|l|}{1991} & \multicolumn{2}{|l|}{1999} & \multicolumn{2}{|l|}{1979} & \multicolumn{2}{|l|}{1991} & \multicolumn{2}{|l|}{1999} \\
\hline & $\mathrm{N}$ & $\mathrm{B}$ & $\mathrm{N}$ & $\mathrm{B}$ & $\mathrm{N}$ & B & $\mathrm{N}$ & B & $\mathrm{N}$ & $\mathrm{B}$ & $\mathrm{N}$ & $\mathrm{B}$ \\
\hline $\begin{array}{l}\text { Littorina saxatilis } \\
\text { Olivi }\end{array}$ & 3,233 & 116.4 & 15 & 6.0 & 18 & 6.3 & 567 & 20.4 & 8 & 0.6 & 100 & 1.1 \\
\hline Mya arenaria $\mathrm{L}$. & 10 & 106.2 & 260 & 138.4 & 2 & 5.4 & 26 & 34.4 & 202 & 109.9 & 2 & 6.0 \\
\hline Macoma balthica $\mathrm{L}$. & 655 & 82.5 & 44 & 9.4 & 668 & 35.0 & 726 & 61.4 & 32 & 18.0 & 872 & 46.2 \\
\hline Mytilus edulis L. & 17 & 40.5 & 5 & 4.0 & 20 & 1.1 & 49 & 104.4 & 18 & 20.8 & 84 & 7.2 \\
\hline Polychaeta var. & 1,327 & 9.1 & 160 & 5.3 & 6 & 0.2 & 988 & 10.3 & 169 & 6.2 & 154 & 6.3 \\
\hline $\begin{array}{l}\text { Hydrobia ulvae } \\
\text { Pennant }\end{array}$ & 1,280 & 7.7 & 8,080 & 4.0 & 2,260 & 16.4 & 4,080 & 20.2 & 3,800 & 30.0 & 3,760 & 26.3 \\
\hline Gammaridae g. sp. & 37 & 2.9 & 48 & 3.2 & 60 & 4.0 & 30 & 2.4 & - & - & 500 & 0.1 \\
\hline Oligochaeta var. & 3,000 & 2.3 & 1,300 & 0.2 & 1,180 & 1.2 & 1,032 & 0.8 & 2,400 & 1.6 & 1,580 & 2.1 \\
\hline Nemertini var. & 32 & + & - & - & - & - & 21 & 0.2 & - & - & - & - \\
\hline Nematoda var. & 32 & + & 350 & + & 2,540 & + & - & - & 3,680 & + & 2,640 & + \\
\hline $\begin{array}{l}\text { Halicriptus } \\
\quad \text { spinulosus Siebold }\end{array}$ & - & - & - & - & 20 & + & 18 & 1.9 & - & - & 54 & 1.3 \\
\hline $\begin{array}{l}\text { Priapulus caudatus } \\
\text { Lamark }\end{array}$ & - & - & - & - & - & - & - & - & - & - & 12 & 0.5 \\
\hline $\begin{array}{l}\text { Jaera albifrons } \\
\quad \text { Leach }\end{array}$ & - & - & - & - & 80 & 0.1 & - & - & - & - & 40 & + \\
\hline Total & 9,623 & 367.6 & 10,262 & 170.5 & 6,854 & 69.9 & 7,537 & 256.4 & 10,309 & 187.1 & 9,798 & 97.2 \\
\hline
\end{tabular}

where $L_{t}$ is the shell length $(\mathrm{mm})$ at time $t$ (year); $L_{\infty}, k$ and $t_{\mathrm{o}}$ are constants. Calculation of constants was performed analytically using an approach described earlier (Maximovich 1989b). The comparison of growth patterns was carried out using the analysis of residual dispersion values with regard to growth 'curves' (Allen 1976; Maximovich 1989b). Significance of dispersion distinctions was estimated using the Fisher index $(F)$. As a distance between the growth patterns, the $F$ to $F$ critical ratio $\left(F / F_{\mathrm{Cr}}\right)$ was used.

The investigated habitats are very typical of the White Sea (Babkov and Golikov 1984). They are characterised by semidiurnal tides with a mean tidal range of about $2 \mathrm{~m}$. In summer, the temperature of the upper water layer rises up to $15-17^{\circ} \mathrm{C}$, in winter it falls to $-1.5^{\circ} \mathrm{C}$. From November to the end of May, the intertidal zone is covered by ice up to $1 \mathrm{~m}$ in thickness. Sampling locations were about $3 \mathrm{~km}$ apart and were characterised by relatively weak wave activity (see Fig. 1). They did not differ much in respect of both bottom slope $\left(5-6^{\circ}\right)$ and character of sediments (average particle diameter $11-13 \mu \mathrm{m})$.

Location A occupied a stretch of the tidal zone in the halfclosed bight (see Fig. 1). Maximal depth of the bight is $9 \mathrm{~m}$, and it is connected with the open water area by a narrow strait only $1 \mathrm{~m}$ deep at low tide. Because of a nearby river mouth, salinity of the bight surface water was relatively low, not exceeding $14-17 \%$ o in summer time (Maximovich 1989a). Strong tidal currents cause relatively strong water dynamics here. The sampling plots were allocated at clay-sandy tidal flats of $30-40 \mathrm{~m}$ width (measured perpendicular to the shoreline). M. arenaria was a typical element of local intertidal macrozoobenthos assemblages throughout the observation period. It dominated in macrozoobenthic assemblages in terms of biomass in both low and middle intertidal horizons. In 1990 soft-shell clams formed $90-91 \%$ of the total macrozoobenthos 
biomass, and $14-23 \%$ of the total macrozoobenthos number in this area (Table 1).

Location B was part of a clay-silt-sandy beach of $50 \mathrm{~m}$ width in a wide shallow bight. Its depth was up to $1 \mathrm{~m}$ at low tide while water dynamics was represented mostly by weak tidal currents. Salinity ranged between $20 \%$ and $23 \%$ o in summer. During the period of observation, drastic changes in the composition of local benthic assemblages were recorded. Until 1982, the middle tidal zone was occupied by a Fucus vesiculosus assemblage, with algae attached to numerous small stones. Bivalves Macoma balthica prevailed in terms of biomass in the macrozoobenthos (Table 2; Maximovich et al. 1991). The low littoral zone was occupied by the Mytilus edulis $+M$. balthica assemblage. In the lowest parts of this horizon, a narrow belt (5-10 m wide) of the sea grass Zostera marina was present, spreading down to the upper sublittoral zone.

During summer 1982 and winter 1982/1983, the oldest specimens of $M$. balthica became largely eliminated. After 1982, an occasional abundant spat of $M$. balthica was reported here, especially in the low intertidal zone, but until 1992 there was no restoration of beds of this species. Abundant settlement of $M$. arenaria took place at this location in 1988. In 1991-1993, softshell clams dominated in terms of biomass, while $M$. balthica was scarce (Table 2). Nevertheless, by 1997 less than $1 \%$ of the $M$. arenaria observed in 1989 survived at this plot. Since 1992, an increase of $M$. balthica abundance was observed in both intertidal horizons, and in 1997-1999 this species again prevailed in terms of biomass in the macrozoobenthos assemblages (Table 2).

\section{Results}

Dynamics of bed structure

\section{Location A}

Highest biomass of $M$. arenaria $\left(1,166 \mathrm{~g} \mathrm{~m}^{-2}\right)$ was recorded in the low intertidal zone in 1994. Maximum abundance in the middle ( 845 ind. $\mathrm{m}^{-2}$ ) and in the low intertidal zone (2168 ind. $\mathrm{m}^{-2}$ ) were recorded in 1990 and 1989 , respectively. Oldest specimens (17 years old, $79 \mathrm{~mm}$ shell length) were found here in 1992 in the low intertidal horizon.

The pilot study of $M$. arenaria population structure in this area was carried out in 1980-1986 (Maximovich 1989a). The main peculiarity of the age structure was a predominance of 2-3 subsequent generations in several years. In 1980, specimens of 30-50 mm shell length (40 $\mathrm{mm}$ on average) prevailed (Fig. 2). This group could be followed up to 1986 (Fig. 2). From 1980 to 1986, juveniles (i.e. specimens settled in the previous year) were scarce or even absent.

By 1987, M. arenaria had virtually disappeared from this location. But, in the summer 1989, in both middle and low tidal horizons, soft-shell clam juveniles were observed in abundance, originating obviously from mass settlement in 1988. In 1989, the number of juveniles in the low intertidal zone was as high as 2152 ind. $\mathrm{m}^{-2}$, while abundance of other generations was as low as 16 ind. $\mathrm{m}^{-2}$ (Table 3 ). In the middle intertidal zone, the corresponding values were 810 ind. $\mathrm{m}^{-2}$ and 32 ind. $\mathrm{m}^{-2}$, respectively. This 1988 generation could clearly be followed until the last observation in 1999 (Fig. 3). Interestingly, until the end of the observation period no mollusc of age $0+$ was recorded from this plot (Table 3,

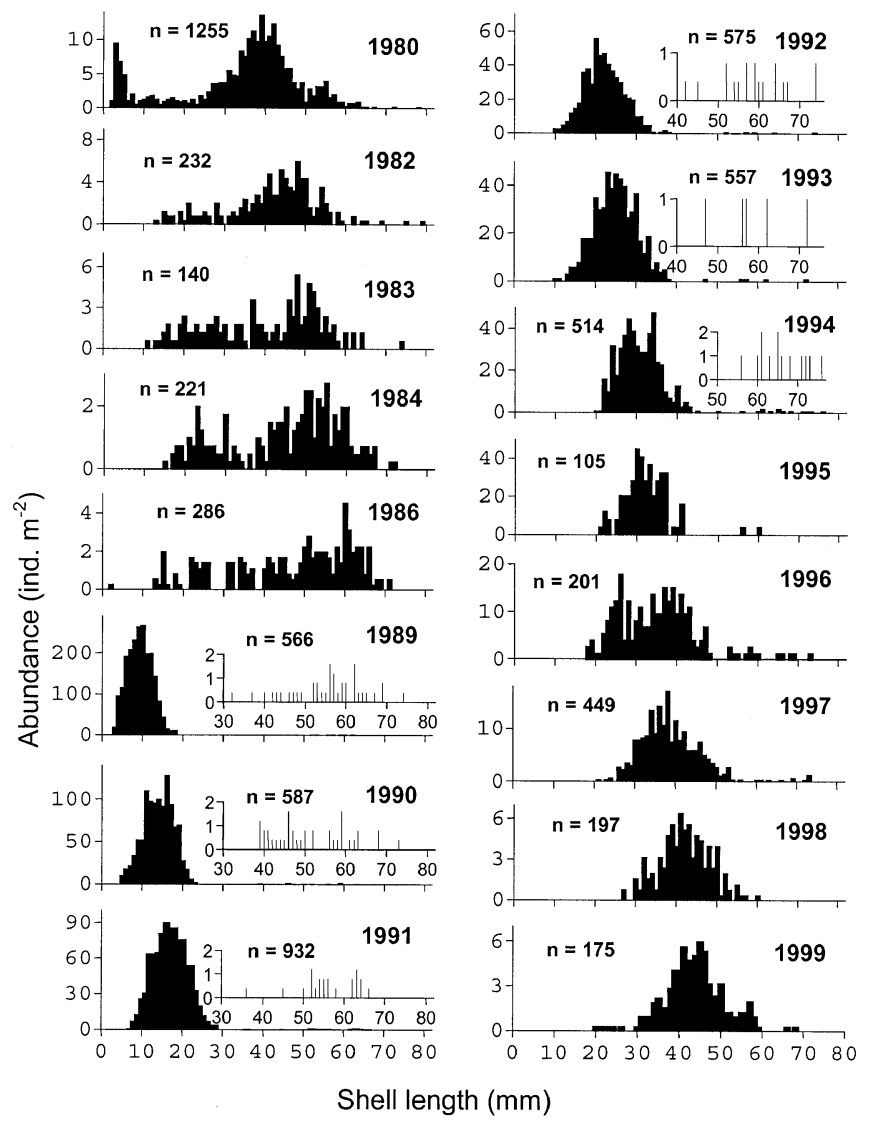

Fig. 2 Length-frequency distribution of Mya arenaria in the low intertidal zone at location A in 1980-1999

Fig. 2). In 1997, just as in 1980, the dominating generation comprised individuals of $30-50 \mathrm{~mm}$ shell length, with an average length of $40 \mathrm{~mm}$ (Fig. 2). Even the abundance of the dominating generation in 1997 was about the same as in 1980 (about 200 ind. $\mathrm{m}^{-2}$ ).

\section{Location B}

The highest number of soft-shell clams for the whole study was recorded in 1989 (obviously due to specimens settled in 1988). Abundance was 677 ind. $\mathrm{m}^{-2}$ and 1,151 ind $\mathrm{m}^{-2}$ in the middle and low intertidal zones, respectively, with juveniles making up 673 and 1,142 ind. $\mathrm{m}^{-2}$ (Figs. 3, 4). After 1989 no further Mya settlement was observed at this location (Fig. 4). From 1989 to 1996, the clam abundance declined gradually (Figs. 3, 4). However, until 1996 the species dominated in terms of biomass in the macrozoobenthic assemblages (Table 2). In 19971999, M. arenaria was not recorded from this plot any more. Meanwhile, the M. balthica population had recovered, their abundance in 1999 was 668 ind. $\mathrm{m}^{-2}$ and 872 ind. $\mathrm{m}^{-2}$ in the middle and low intertidal zones, respectively (Table 2).

Thus, in both investigated locations the 1988 generation of M. arenaria developed on the background of an 


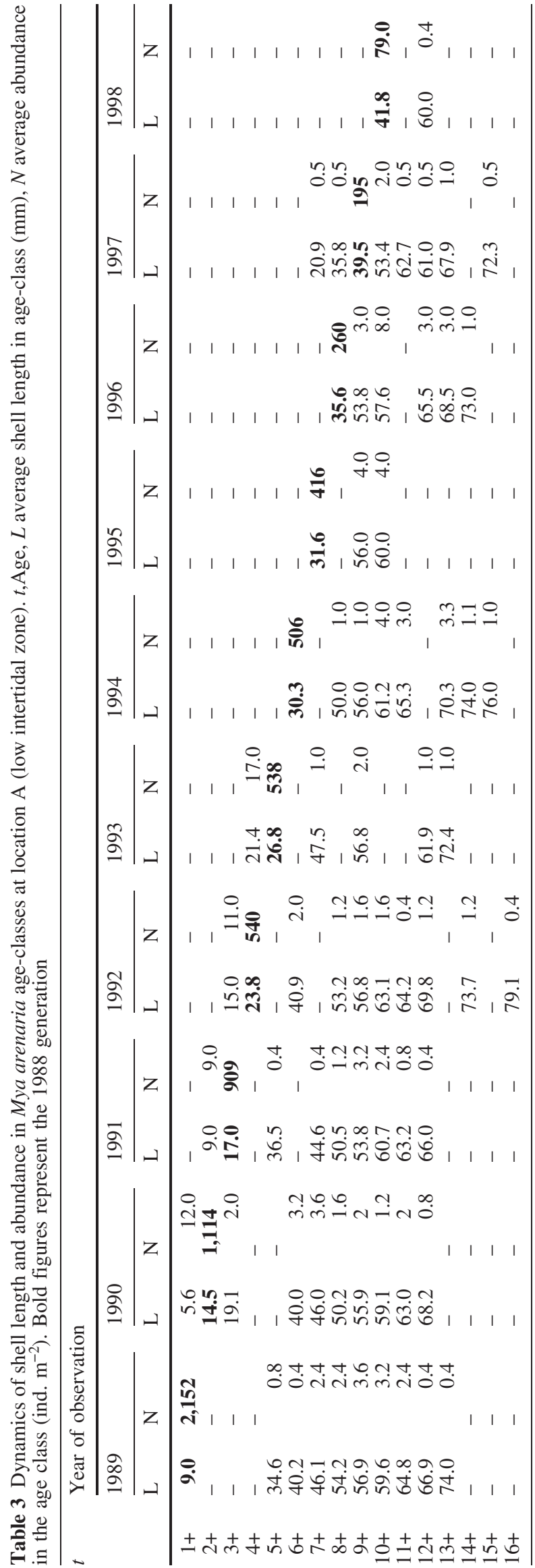

almost complete lack of subsequent recruitment and a low abundance of older specimens. The characteristics of growth and abundance dynamics of $M$. arenaria will be analysed in the following mostly on the basis of this 1988 generation.

Abundance dynamics of generations

Abundance of separate $M$. arenaria year-classes varied over a wide range (see Fig. 3). The sharpest annual abundance decline (50-85\%) was reported for 1 to 2 year-old molluscs. Later on, $1-60 \%$ of a generation were eliminated each year. Some stabilisation of 1988 generation abundance was observed in 1992-1995 at location A, and in 1990-1993 at location B (see Figs. 2, $4)$. The mortality coefficient $(\mu)$ varied substantially between sites (from 0 to 1.68 year $^{-1}$ ), but a general trend could be found (Fig. 5). Until the age of approximately 6 years, the mortality coefficient for individual cohorts decreased almost down to zero, while for older molluscs $\mu$ showed an obvious tendency to increase again.

Average values of $\mu$ for the investigated $M$. arenaria beds were 0.4 year $^{-1}$ in the middle intertidal zone and 0.8 year $^{-1}$ at the low intertidal zone. Though average values differed substantially, the range of fluctuations was similar for both tidal levels: $0.01-1.48$ and $0-1.68$ for middle and low intertidal zones, respectively. Within each of the investigated locations, the mortality coefficients varied to a similar degree: from 0 to 0.90 year $^{-1}$ at location A, and from 0.01 to 1.68 year $^{-1}$ at location B. The mean values, however, were fairly close to each other: 0.4 year $^{-1}$ and 0.6 year $^{-1}$, respectively.

\section{Growth rate}

The two investigated locations differed markedly in terms of size of specimens of the 1988 generation over the whole study period (Fig. 3). To compare growth rates of $M$. arenaria at different sites, specimens of the 1988 generation were collected in 1996 (when they were 8 years old) (Tables 4, 5, 6). 1996 was chosen because this was the last year that the clams were collected from all four studied sites.

The average growth rate at location A was significantly higher than that at location B (Fig. 6). At location $\mathrm{B}$, no significant difference in growth rate was found between low and middle intertidal zones. At location A, however, specimens from the low intertidal zone had a significantly higher growth rate than those from the middle intertidal zone. Nevertheless, confidence intervals for the average values of shell length in separate years widely overlap (Fig. 6). 
Fig. 3 Dynamics of average shell length (upper diagrams) and abundance (lower diagrams) of the 1988 generation
Low tidal level
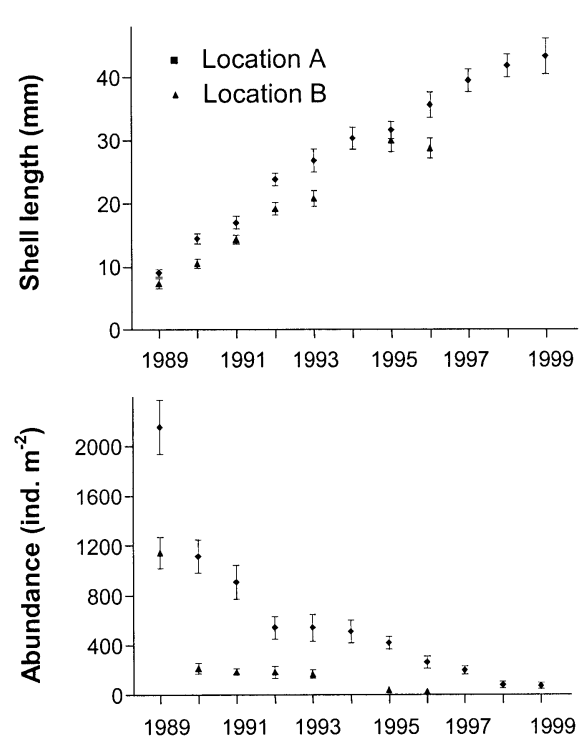

Middle tidal level
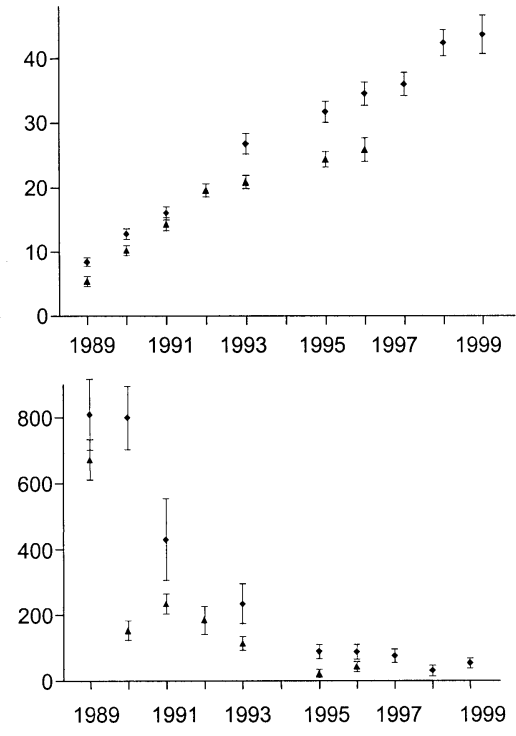

Time (year)

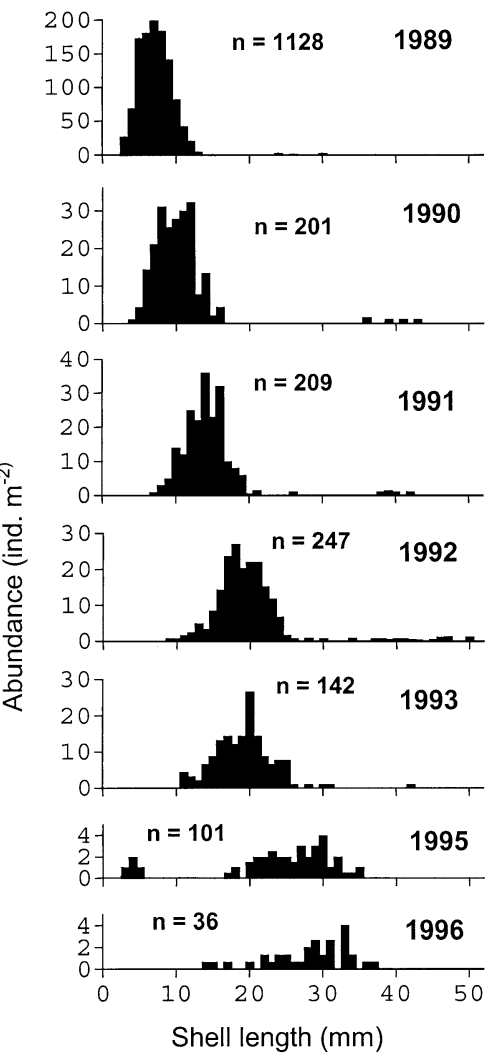

Fig. 4 Length-frequency distribution of $M$. arenaria in the low intertidal zone at location B in 1989-1996

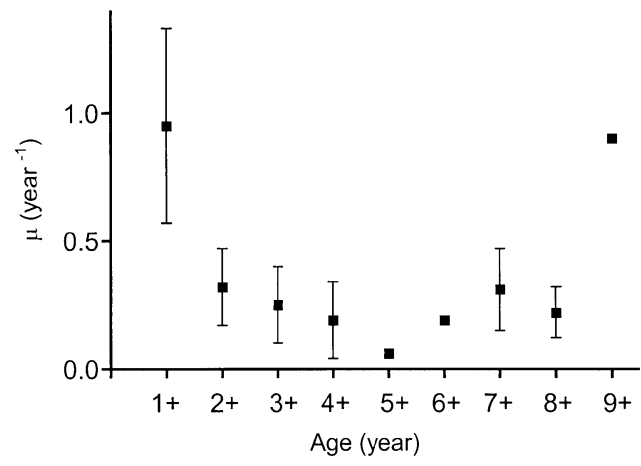

Fig. 5 Changes of the mortality coefficient $(\mu)$ with age. Means and standard errors (vertical lines)

\section{Discussion}

A long-term monitoring is probably the most adequate approach to the analysis of population dynamics in longliving benthic species. In our study, the period of observation (19 years) exceeded the life span of $M$. arenaria in the White Sea, which is up to 17 years according to our data. A main feature of the investigated beds is instability of age structure. As a result of substantial annual variation in the number of specimens of age $0+$, a single generation prevailed in the beds for several years. Since 1989, other generations were represented by a few specimens only. The period of the population cycle could be derived from the data obtained at location A. The switch between generations took place there in 1988. The striking resemblance of the studied Mya beds in 1980 and in 1997, in terms of both clam average size and abundance of the dominating group, 
Table 4 Comparative analysis of growth curves of the 1998 generation from different sites. $k, L$ and $t_{\mathrm{o}}$, coefficients of the von Bertalanffy equation; $v$ degrees of freedom $(v=N-3)$; $S S$ deviance; $S^{2}$ variance; $F, F$-ratio; $F_{\text {cr }}$ critical value $(<0.05) . M L$ Middle intertidal zone, $L L$ low intertidal zone; A, B, investigated locations as in Fig. 1. Results of individual growth reconstruction on the basis of shell annuli measurements

\begin{tabular}{|c|c|c|c|c|c|c|c|c|c|c|c|c|}
\hline \multirow[t]{2}{*}{ Sampling site } & \multicolumn{7}{|c|}{ Average shell length during winter growth delay $(\mathrm{mm})$ at age: } & \multicolumn{5}{|c|}{ Parameters of growth models } \\
\hline & $1+$ & $2+$ & $3+$ & $4+$ & $5+$ & $6+$ & $7+$ & $k$ & $L$ & $t_{\mathrm{o}}$ & SS & $S^{2}$ \\
\hline $\mathrm{A}(\mathrm{ML})$ & 8.8 & 16.4 & 22.3 & 26.1 & 30.5 & 34.0 & 37.1 & 0.195 & 49.4 & 0.965 & 0.904 & 0.226 \\
\hline $\mathrm{A}(\mathrm{LL})$ & 9.7 & 16.4 & 22.9 & 27.6 & 32.1 & 36.4 & 39.5 & 0.144 & 61.4 & 0.810 & 0.253 & 0.063 \\
\hline B(ML) & 8.0 & 12.7 & 16.9 & 20.5 & 23.0 & 26.2 & 28.6 & 0.136 & 44.8 & 0.540 & 0.245 & 0.061 \\
\hline $\mathrm{B}(\mathrm{LL})$ & 8.7 & 12.3 & 16.3 & 19.6 & 22.6 & 25.8 & 28.3 & 0.071 & 65.7 & 0.016 & 0.121 & 0.030 \\
\hline
\end{tabular}

Table 5 Analysis of residual variances in relation to growth models

\begin{tabular}{llrrrl}
\hline Source of variation & $v$ & \multicolumn{1}{l}{$S S$} & $S^{2}$ & $F$ & $F_{\text {cr. }}$ \\
\hline Separate equations & 16 & 1.52 & 0.095 & & \\
Common equation & 25 & 365.97 & 14.639 & 153.8 & 2.23 \\
\hline
\end{tabular}

Table 6 Two by two comparison of growth curves. Dissimilarity ratio as $F / F_{\text {cr. }}$.

\begin{tabular}{lccl}
\hline Sampling site & $\mathrm{A}(\mathrm{ML})$ & $\mathrm{A}(\mathrm{LL})$ & $\mathrm{B}(\mathrm{ML})$ \\
\hline $\mathrm{A}(\mathrm{LL})$ & 1.8 & - & - \\
B(ML) & 25.530 & 91.25 & - \\
B(LL) & 32.67 & 134.84 & 0.82 \\
\hline
\end{tabular}

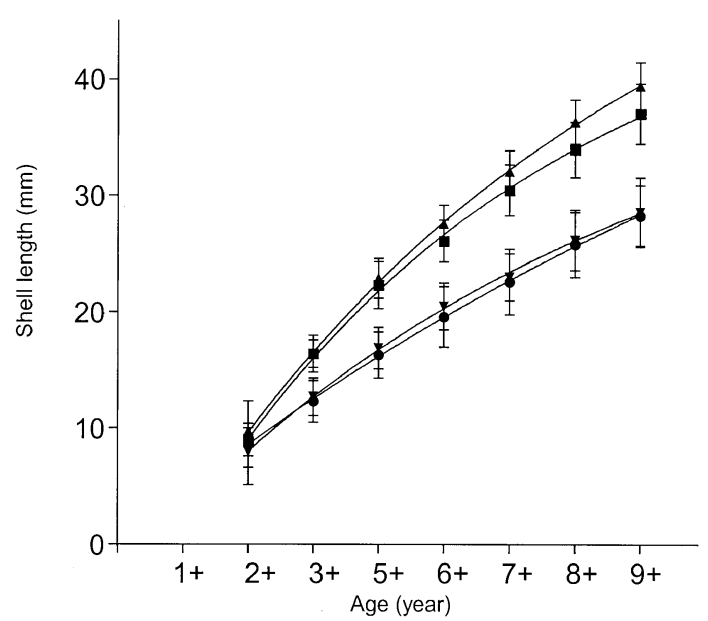

Fig. 6 Reconstruction of $M$. arenaria growth patterns. Rectangles Location A, middle intertidal zone; upper triangles location A, low intertidal zone; lower triangles location B, middle intertidal zone; circles location B, low intertidal zone. Vertical lines indicate $95 \%$ confidential intervals

suggests that the period of this bed cycle was close to 17 years.

Predominance of a single generation in local $M$. arenaria populations was also reported from the Wadden Sea (Strasser et al. 1999). A number of studies demonstrated drastic (Smidt 1944; Goshima 1982) as well as cyclic (Glude 1954; Commito 1982; Sadykhova 1982) changes in the population structure of this species in different parts of its geographical range. These peculiarities of soft-shell clam population dynamics could be connected to interannual variation in recruitment rate, which in turn might result from interannual variation in reproductive success (Beukema 1982, 1992). However, this is probably not the case in the White Sea, since environmental conditions during the hydrological summer period are quite favourable for $M$. arenaria reproduction (Kaufman 1977; Maximovich 1978), and larvae were observed regularly in relatively large numbers in the summer plankton of the Chupa Inlet (Maximovich and Shilin 1990, 1993, 1997). Abundance of veliconches in planktonic assemblages of this area varied between years, with maximum values of up to 300 ind. $\mathrm{m}^{-3}$, and there were no extraordinary events in 1988 in this respect (Maximovich and Guerassimova unpublished data).

Obviously, the key factors for successful recruitment were the conditions of spat settlement and juvenile survival. In the Wadden Sea, the number of M. arenaria recruits was found to be negatively correlated to the abundance of the lugworm Arenicola marina, which is a dominant bioturbator on the intertidal flats of that area (Flach 1992). However, lugworms are not characteristic of the investigated locations in the White Sea (Maximovich 1989a; Maximovich et al. 1991). Predation has also been identified as an important regulator of abundance of soft-shell clam juveniles (Pihl 1982; Jensen and Jensen 1985; Reise 1985; Günther 1992). For example, the crab Carcinus maenas played a key role in the elimination of the $0+$ group of $M$. arenaria in the Danish Wadden Sea (Jensen and Jensen 1985). Nevertheless, epibenthic predators could hardly be responsible for the lack of Mya recruitment at location A throughout an 11year period. There is also no reason to suggest an impact of annual changes in the hydrological regime in the investigated area on the year-to-year variation in the abundance of $0+$ specimens. In 1988, when intensive recruitment took place in both habitats, no anomalies were observed in basic hydrological characteristics (including salinity and temperature).

A number of authors reported a negative influence of filter feeders on their planctonic larvae (Woodin 1976; Olafsson 1989). As a result of this kind of impact, intraspecific competition in soft-shell clam beds was observed (Möller and Rosenberg 1983; Möller 1986; Andre and Rosenberg 1991). Thus, successful spat 
settling in habitats typical of this species could be expected only when the number of adult specimens is low. Characteristically, during our study mass settlement at location A (in 1988) took place after almost complete elimination of other Mya generations (Fig. 2). However, to assume that successful recruitment of soft-shell clams is only possible when the number of older specimens is low would probably oversimplify the mechanisms of population dynamics. There is a lot of data available about a lack of correlation between the number of spat and number of adult specimens in $M$. arenaria local populations (Kühl 1955; Brousseau and Baglivo 1988; Günter 1992; Strasser et al. 1999).

The obvious synchrony of $M$. arenaria bed dynamics in both investigated habitats suggests the existence of a common mechanism regulating recruitment rate and periodicity in these areas. Abundant juveniles in both locations probably appeared due to: (1) availability of an unoccupied biotope in 1988; and (2) favourable conditions for juvenile survival during the first winter. In particular, ice conditions are known to be of crucial importance for M. arenaria spat survival (Kühl 1951).

At location $\mathrm{B}$, the formerly dominant species $M$. balthica was replaced by $M$. arenaria. It is well known that spatial distribution and lifecycles of marine organisms in the White Sea are largely determined by temperature and salinity gradients (Kuznetzov 1960; Kaufman 1977). Nevertheless, the replacement took place under an ordinary hydrological regime and cannot be explained by changes in thermo-haline environmental characteristics. Known competitive interactions between M. balthica and M. arenaria (Rassmussen 1973) and temporary advantage of one species under the given environmental conditions may have been decisive for the redirection of community succession.

Variability of the elimination rate, which we observed in the investigated beds, was also reported for other parts of the species' geographical range (Brousseau 1978; Commito 1982; McGroty et al. 1990). In Northern America, as well as in the White Sea, larvae and juveniles of $M$. arenaria have been reported to show the highest elimination rates, while in older specimens the elimination rate decreases (Brousseau 1978; Commito 1982). The high mortality level during the first (1-2) years of the life cycle may be connected to the fact that young clams of this age inhabit the highly changeable surface sediment layer (not deeper than 2-3 cm). For example, it is known (Kulakovsky and Flachinskaja 1993) that among larvae of Mytilus edulis in the White Sea there are quite a lot of specimens with visible ontogenetic defects. The relatively low rate of mortality of 3- to 6-year-old Mya arenaria may be related both to a decreased variability of the environment (clams of this age live deeper in the sediments) and to improved feeding conditions (after elimination of a large part of the generation). A subsequent re-increase in the elimination rate might reflect growing competition among larger molluses with their increased food demands.
The growth rate of the soft-shell clam varies considerably in different parts of its geographical range. The maximum lifetime varied from 4 to 28 years, while maximum length ranged from 27 to $125 \mathrm{~mm}$ (Swan 1952; Feder and Paul 1974; Warvick and Price 1975; Evans and Tallmarc 1977; MacDonald and Thomas 1980; Commito 1982; Emerson et al. 1988; Appeldoorn 1990). In the Mya beds studied here, molluscs reached $74-79 \mathrm{~mm}$ in 13 17 years, which corresponds well to the above data.

Substantial differences between the investigated locations with respect to mollusc life history (at location B the 1988 M. arenaria generation went extinct after 8 years, whereas at location A the same generation reached 11 years still at a relatively high abundance) may reflect differences in habitat characteristics and life conditions in spite of a high outward resemblance of the two locations. Though the data obtained did not reveal significant differences between locations $\mathrm{A}$ and $\mathrm{B}$ with respect to elimination rate, they did show significant differences in growth patterns. The growth rate in $M$. arenaria is known to be strongly related to temperature (Swan 1952; Appeldoorn 1990) and food availability (Rosenberry et al. 1991). However, inside the investigated area neither substantial temperature gradients nor signs of differences in food availability were observed. Thus the differences in $M$. arenaria growth rates may be related to some other factors which are still unknown. It is nevertheless clear that $M$. arenaria growth rate is very sensitive to environmental conditions. Considering definite bioindicator properties of the soft-shell clam, we suggest that this species is a convenient and promising object for population monitoring.

Acknowledgements We thank the students of the Department of Ichthyology and Hydrobiology at St. Petersburg State University for assistance in mollusc sampling. The studies were funded by the Russian Foundation for Basic Research and the Program 'Universities of Russia-fundamental researches'. The investigations comply with the current laws of the Russian Federation.

\section{References}

Allen RL (1976) A method of comparing fish growth curves. N Z J Mar Freshw Res 10:687-692

Andre C, Rosenberg R (1991) Adult-larval interactions in the suspension-feeding bivalves Cerastoderma edule and Mya arenaria. Mar Ecol Prog Ser 71:227-234

Appeldoorn RS (1983) Variation in the growth rate of Mya arenaria and its relationship to the environment as analyzed through principal component analysis and the $\mathrm{w}$ parameter of von Bertalanffy equation. Fishery Bull Fish Wildl Serv US 81:75-85

Appeldoorn RS (1990) Covariation in life history parameters of soft-shell clams, Mya arenaria along a latitudinal gradient. In: Abstracts of the Symposium on shellfish life history and shellfishery models, Moncton, 1990, pp 19-26

Babkov AI, Golikov AN (1984) Hydrobiocomplexes of the White Sea (in Russian). Zoological Institute, Leningrad

Beukema JJ (1982) Annual variation in reproductive success and biomass of the major macrozoobenthic species living in a tidal flat area of the Wadden Sea. Neth J Sea Res 16:37-45

Beukema JJ (1992) Expected changes in the Wadden Sea benthos in a warmer world: lessons from periods with mild winters. Neth J Sea Res 30:73-79 
Brousseau DJ (1978) Population dynamics of the soft-shell clam Mya arenaria. Mar Biol 50:63-72

Brousseau DJ (1979) Analysis of growth rate in Mya arenaria using the Von Bertalanffy equation. Mar Biol 51:221-227

Brousseau DJ, Baglivo JA (1984) Sensitivity of the population growth rate to changes in single life history parameters: its application to Mya arenaria (Mollusca: Pelecypoda). Fish Bull 82:537-540

Brousseau DJ, Baglivo JA (1988) Life tables for two field populations of soft-shall clam, Mya arenaria, (Mollusca: Pelecypoda) from Long Island Sound. Fish Bull 86:567-579.

Commito JA (1982) Effects of Lunatia heros predation on the population dynamics of Mya arenaria and Macoma balthica in Maine, USA. Mar Biol 69:187-193

Emerson CW, Minchinton TE, Grant J (1988) Population structure, biomass, and respiration of Mya arenaria L. on temperate sandflat. J Exp Mar Biol Ecol 115:99-111

Evans S, Tallmark B (1977) Growth and biomass of bivalve molluses on a shallow, sandy bottom in Gullmar Fjord (Sweden). Zoon 5:33-38

Feder HM, Paul AJ (1974) Age, growth and size-weight relationships of the soft-shell clam, Mya arenaria, in Prince William Sound, Alaska. Proc Natl Shell Assoc 64:45-51

Flach EC (1992) Disturbance of benthic infauna by sedimentreworking activities of the lugworm Arenicola marina. Neth $\mathrm{J}$ Sea Res 30:81-89

Glude JB (1954) The effects of temperature and predators on the abundance of the soft-shell clam, Mya arenaria, in New England. Trans Am Fish Soc 14:13-26

Golikov AN, Skarlato OA, Maximovich NV, Matveeva TA, Fedjakov VV (1985) Fauna and ecology of shell molluscs of the Chupa Inlet of the White Sea (in Russian). Issledovanija Fauny Morey 31 (39): 185-229

Goshima S (1982) Population dynamics of the soft clam, Mya arenaria L., with special reference to its life history pattern. Publ Amakusa Mar Biol Lab Kyushu Univ 6:119-165

Günter CP (1991) Settlement of Macoma balthica on an intertidal sand-flat in the Wadden Sea. Mar Ecol Prog Ser 76: 73-79

Günter CP (1992) Settlement and recruitment of Mya arenaria L. in the Wadden Sea. J Exp Mar Biol Ecol 159:203-215

Ivanov AI (1973) Introduction of mollusc Mya arenaria L. into the Black Sea: geographical range extension, population dynamics and some biological features in new conditions (in Russian). Materials of All-Union Symposium on explorations of the Black Sea and the Mediterranean Sea, utilization and preservation of biological resources, pp 58-60

Jensen KT, Jensen JN (1985) The importance of some epibenthic predators on the density of juvenile benthic macrofauna in the Danish Wadden Sea. J Exp Mar Biol Ecol 89:157-174

Kaufman ZS (1977) Peculiarities of sex cycles in the White Sea invertebrates (in Russian). Nauka, Leningrad

Kühl H (1951) Uber die Siedlungsweise von Mya arenaria. Verh Dtsch Zool Ges 25:385-391

Kühl H (1955) Studien uber die Klaffmuschel Mya arenaria. 3. Das Junggut. Arch Fisch Wiss 6:33-44

Kulakovsky EJ, Flachinskaja LP (1993) Peculiarities of larvae development in the White Sea mussels (Mytilus edulis L.). Formation of regulatory system elements (in Russian). Proc Zool Inst Russ Acad Sci 253:61-82

Kuznetzov VV (1960) The White Sea and biological peculiarities of its flora and fauna (in Russian). Nauka, Moscow, St. Petersburg

MacDonald BA, Thomas ML (1980) Age determination of the softshell clam Mya arenaria using shell internal growth lines. Mar Biol 58:105-109

Maximovich NV (1978) Peculiarities of ecology and bioenergetic traits of population of $M$. arenaria L. (Bivalvia) in the Chupa Inlet (in Russian). Vestnik LGU, Ser 3, 21:28-36

Maximovich NV (1989a) Dynamics of production traits in littoral settlement of Mya arenaria L. (The Chupa Inlet, The White Sea) (in Russian). Vestnik LGU, Ser 3, 1:19-24

Maximovich NV (1989b) Statistical comparison of growth curves (in Russian). Vestnik LGU, Ser 3, 4:18-25
Maximovich NV, Shilin MB (1990) Spatial distribution and dynamics of larvae of mass mollusc species in the Chupa Inlet (the White Sea). In: Biological monitoring of inshore zone of the White Sea (in Russian). Institute of Oceanology, Moscow, pp 83-91

Maximovich NV, Shilin MB (1993) The larvae of bivalve molluscs from plankton of the Chupa Inlet (The White Sea) (in Russian). Explor Sea Fauna 45 (53): 131-137

Maximovich NV, Shilin MB (1997) The structure of Bivalvia larvacene in the Chupa Inlet (the White Sea). In: Ecological investigations of the White Sea organisms. Materials of the international conference, July 1997, BBS RAS (Kartesh, White Sea), pp 52-54

Maximovich NV, Guerasimova AV, Kunina TA (1991) Dynamics of structural characteristics in littoral settlements of Macoma balthica L. in the Chupa Inlet (the White Sea) (in Russian). Vestnik LGU, Ser 3, 2:23-31

McGroty S, Clarke RT, Reading CJ, Goss-Custard JD (1990) Population dynamics of the mussel Mytilus edulis: density changes and regulation of the population in the Exe estuary, Devon. Mar Ecol Prog Ser 67:157-169

Möller P (1986) Physical factors and biological interactions regulating infauna in shallow boreal areas. Mar Ecol Prog Ser 30:33-47

Möller P, Rosenberg K (1983) Recruitment, abundance and production of Mya arenaria and Cardium edule in marine waters. Western Sweden. Ophelia 22:33-35

Münch-Petersen S (1970) An investigation of a population of the soft clam (Mya arenaria L.) in a Danish estuary. Medd Dan Fisk-og Havunders. 7 (1-3): 47-73

Newcombe CL (1936) Variations in growth indices of $M y a$ arenaria L. on the Atlantic coast of North America. Ecology 17:29-43

Newell CR, Hidu H (1982) The effects of sediment type on growth rate and shell allometry in the soft shelled clam Mya arenaria L. J Exp Mar Biol Ecol 65: 285-295

Olafsson EB (1989) Contrasting influences of suspension-feeding and deposit-feeding populations of Macoma balthica on infaunal recruitment. Mar Ecol Prog Ser 55:171-179

Pihl L (1982) Food intake of young cod and flounder in a shallow bay on the Swedish west coast. Neth J Sea Res 15:419-432

Rasmussen E (1973) Systematics and ecology of the Ice-Fjord Marine Fauna (Denmark). Ophelia 11:1-507

Reise K (1985) Tidal flat ecology. Springer, Berlin Heidelberg New York

Rosenberry L, Vincent B, Lemaire C (1991) Croissance et reproduction de Mya arenaria dans la zone intertidale de l'estuaire du Saint-Laurent. Can J Zool 69:724-732

Russanova MN (1963) Short notes on biology of some mass invertebrate species in the vicinity of the cape Kartesh. In: Materials of integrated research of the White Sea. 2 (in Russian). USSR Academy of Science, Moscow-Leningrad, pp 53-65

Sadykhova IA (1979) Some peculiarities of the Mya arenaria L. beds in the White Sea. In: Molluscs. Main results of their investigations. 6 (in Russian). Leningrad, pp 77-78

Sadykhova IA (1982) Changes in abundance and size-frequency distribution of Mya arenaria $\mathrm{L}$. population in the White Sea. In: Proceedings of 1st coordination meeting entitled Productivity increase, sustainable use and conservation of the White Sea natural resources (in Russian). Leningrad, pp 73-74

Smidt ELB (1944) The effects of icewinters on marine littoral faunas. Folia Georg Dan 2 (3): 1-36

Strasser M, Walensky M, Reise K (1999) Juvenile-adult distribution of the bivalve Mya arenaria in the Wadden Sea: why are there so few year classes? Helgol Mar Res 53:45-55

Swan EF (1952) Growth indices of the clam Mya arenaria. Ecology 33:365-374

Warvick RM, Price R (1975) Macrofauna production in an estuarine mud-flat. J Mar Biol Assoc U K 55:1-18

Winther Ul, Gray JS (1985) The biology of Mya arenaria (Bivalvia) in the eutrophic inner Oslofjord. Sarsia 70: 1-9

Woodin SA (1976) Adult-larval interactions in dense infaunal assemblages: Patterns of abundance. J Mar Res 34:25-41 